\title{
Richard Cantillon's Ideologies and Its Implications for Economic Development in Nigeria
}

\author{
${ }^{1}$ Imoisi, Anthony Imoisi, ${ }^{2}$ Sogules, Ipalibo Watson, \\ ${ }^{3}$ Godstime Ikechukwu Opara \\ College of Social \& Management Science, McPherson University, Km 96, Lagos-Ibadan Expressway, Seriki \\ Sotayo, P.M.B. 2094 Abeokuta, Ogun State, Nigeria. \\ College of Graduate Studies, Faculty of Social Sciences, Department of Economics, University of Port \\ Harcourt, P.M.B. 5323, Choba, Rivers State, Nigeria. \\ Department of Economics, Faculty of Social Sciences, Imo State University Owerri, Imo State, Nigeria
}

\begin{abstract}
$\overline{\text { Abstract: This paper examines and ascertains how the contributions of Richard Cantillon have been relevant to }}$ the growth and development of the Nigerian economy. In doing this, the economic thoughts of Richard Cantillon were critically examined in order to see how these issues raised have been affecting the Nigerian economy. Political economy and descriptive approaches were used to x-ray the relevance of Richard Cantillon's contributions to Nigeria's development. His contributions among others include: the nature of wealth, social and economic organization of people, wages of labour, theory of values, population problems and the use of gold and silver, barter, prices, circulation of money, interest rates, foreign trade, foreign exchange and banking and credit. The findings of the study revealed that his contributions are of great relevance to economic development in general, but have not specifically contributed to the development of Nigerian economy. This is seen in the areas of low per capita income of most workers in Nigeria, negative attitude to work especially by those workers in public organizations, inevitable population problems, persistent increase in the general prices of goods and services, high lending rates by the financial institutions operating in the country, unfavourable terms of trade, incessant and diversion of public funds into luxurious consumption rather than investment in the real sectors of the economy, and without doubt Nigeria has no place in foreign trade. Based on the foregoing, it was concluded that all these ugly trends accounted for the reason why economic growth and development is not at sight in Nigeria. Thus, it was recommended that the monetary authorities should initiate sound monetary policies that would encourage investment in the real sectors of the economy; corruption, which is now widespread in the economy should be checked and curtailed, because it has adversely affected economic growth and development of the Nigerian economy. Also, these monetary policies should be complemented with effective fiscal policies in order to put the Nigerian economy back to path of economic growth and development.
\end{abstract}

Keywords: Economic Development, Foreign Trade, Money Supply, Monetary Policies, Fiscal Policies, Interest Rate, Exchange Rate, Wages of Labour

\section{Introduction}

Ordinarily, economic thought would be taken to cover the set of theories, doctrines, laws and generalizations, and analysis applied to the study and solution of economic phenomena and problems. It is worth quoting Bhatia (2006) that the specific contents of economic thought have normally commanded an uneven prominence, some attracting more attention than the others; and the overall composition of economic thought is also subject to continuous variation. Furthermore, he argued that economic thought is not a given and fixed set of economic theories or tools and techniques of analysis. Economics is a dynamic science, a feature that it acquires on an account of various reasons. It therefore follows that economics brings forth a body of generalizations which, as in others sciences, involve cause-effect relationships. Economic ideas have been there since time immemorial, but it is only recently that they assumed the form of a system of thought which may be termed economic science or economics. References to economic questions abound and are scattered almost everywhere in the old literature, such they are found in Plato-Aristotle, and others (Bhatia, 2006). But in all cases, we have only fragments of information, and conclusion are not able to adequately generalize on these economic ideas and economic views with any great significance, we therefore cannot claim the emergence of economic thought.

In that sense, the time when those ideas started getting crystallized into economic thought is around the time of Mercantilism. The birth of economic science might be said to have coincided with the rise of physiocracy, because it is in this system that comprehensive economic theory emerged. Accorsding to a widely held opinion, Adam Smith's book "An inquiry into the nature and causes of the wealth of nations" (published in 1776) was the first systematic work of economic problems, while now modern critics have been more and more 
persuaded and rightly so, to attribute that priority to Richard Cantillon, author of "Essia sur al nature du Commerce, published in 1775".

Arising from the above conversations, it is obvious that economic thought is a body of economic ideas and generalizations which can be seen to belong to each other, and therefore economic thought is closely related to economic environment and economic development. The growth of economic science can be traced along with the growing complexity of world economies. The development of economic science is intimately related to the development of economic environment, and the two interact with each other. This means that economic ideas of the great thinkers in economics are needed for the stimulation of economic development of any economy. This is because the exact nature of responses depends upon the institutional framework of the society and that is the more reason why the customs and behaviour get crystallized into institutions. Economic theorizing and investigation therefore have to be in the context of and within the framework of an economy which has a prescription of achieving economic growth and development.

In this paper therefore, emphasis is on economic development. In this regards, Ohale \& Onyema (2003) opines that economic development has distinctive features from that of economic growth. They saw economic development as the movement of an economy from a less desirable stage to a more desirable stage with every sector and unit of the economy being taken into consideration.

Kalu (2001) defines economic development as consisting of improvements in the various aspects of the life of the entire population of a country. Such improvements are generally manifested in greater numbers of useful jobs for employable persons, higher levels of education (literacy), more and better government services, better agricultural and industrial skills and techniques, higher production, lower personal and regional socioeconomic inequalities, favourable terms of trade, balance of payments surplus, increase in per-capita income, better and workable monetary and fiscal policies and better banking services.

Judging from the foregoing, it is clear that the economic thoughts of Richard Cantillon to the development of economics cannot be over emphasized. Logically, it therefore implies that his economic thoughts, if historically adopted, should bring about economic development in any economy, advanced or otherwise. Akpakpan (1999) in this respect observed that in the book of Richard Cantillon, his contributions to economic thought are organized in various parts namely: the nature of wealth, social and economic organization of people, wages of labour, theory of value, population use and the use of gold and silver; barter, prices, circulation of money, and interest rate; and foreign trade, foreign exchange, and banking and credit.

Given the contributions of Richard Cantillon which covers most significant practices of economics in any country, it therefore becomes imperative to run the analysis of his economic thought and economic development in Nigeria in order to spot out the relevance of his contributions to the Nigeria economy.

Relevant pages of literature and history of economic thought such as (Jhingan, 2007; Marcuzzo, 2008; Bhatia, 2004; Akpakpan, 1999; Tamuno, 2006; Okowa, 1996; Kalu, 2001; Blang, 2001; Todaro and Smith, 2004; and Samuelson and Salow 1960) have consistently revealed that the adoption and complete application of the doctrines, ideas, model, philosophy; in fact all the contributions of economists of old (chronology of the founding fathers) have led to the emergence of the discipline and without doubts equally accorded for the reason why some economies are said to be developed and others are said to be underdeveloped. Obviously, the Nigeria economy is categorized in the latter. This is because Nigeria is grossly under developed and the economy is characterized by high rate of unemployment, very low per capital income and GDP per capita, unfavourable terms of trade, balance of payments deficits, sluggish economic growth, double digit inflation rate, high lending interest rate, lack of access to credit facilities to the economic participants in the real sector, instability in the banking sector and poor socio-economic organizations. It is against this back drop that this paper seeks to address these issues namely: Is Richard Cantillon's economic ideas not relevant in Nigeria? Is his policy not workable in Nigeria? In spite of the fact that the high level of economic development recorded in other economies has been attributed to the adoption and application of history of economic thoughts, which of cause, Richard Cantillon occupies a prominent position; hence, the emergence of this paper.

\section{Richard Cantillon's Contribution To History Of Economic Thought}

In the analysis of the problems so identified by Richard Cantillon, he puts forward a theory of value and price in which he emphasized the influence of labour and land on supply and demand. In trying to explain value, there is a distinction between intrinsic value and market value of a thing. Intrinsic value was determined by 'the amounts of labour and land that go into production' of the good in question, i.e., 'the cost of production, including wages and cost of materials'. He pointed out that these values - the intrinsic value and the market value - were not always equal. Often there were divergences between them due to the relative strength of the forces of demand and supply.

Cantillon introduced the term 'entrepreneur' into economic analysis. He argued that production involved risk-taking, and that profit was the reward for the organizer of production (the entrepreneur) for taking the risk. He used the term 'profit' to justify interest charges for money lent to businessmen. Interest, he 
maintained, was a reward for risk taken in lending since the businessman would make profit by investing the borrowed funds. Cantillon's emphasis on the role of the entrepreneur, the risk-taker, in the production process led to the inclusion of entrepreneurship in the list of factors of production.

Another outstanding contribution of Cantillon was in the area of external trade. He examined the mercantilist's view on external trade and agreed that surplus of exports over imports was good for the country, he also pointed out that a country could not maintain a surplus in its external trade indefinitely. Bhatia (1981) summarizes Cantillon's analysis as thus: 'if a country has an export surplus, and gold flows in, the country supply will increase in the export surplus country. This will push up prices, and thus a consequent reduction in exports will restore the trade balance' (p.44).

Cantillon also analyzed the effect of changes in money supply on the economy. He showed that an increase in money supply within a country would increase purchasing power throughout the system, and that this would have the effect of stimulating economic activities. He extended this argument to an explanation of the circulation of money and commodities in the economy. Most modern students of Cantillon's work have argued that he did not in fact subscribe to the quantity theory of money. That is to say, Cantillon was not prepared to accept the crude monetarist view that, if the money supply increased, prices would rise proportionally (Murphy 2009:85). It is indeed true that the Cantillon made conscious efforts to distance his views from earlier formulations of the quantity theory, specifically those found in John Locke. He does this by examining in detail the channels through which additional quantities of money enter the circular flow of income. From this muchadmired analysis, he concluded: "that by doubling the quantity of money in a state, the prices of products and merchandise is not always doubled". A River which runs and winds about in its bed will not flow with double the speed when the amount of its water is doubled (translation Higgs 1931:177). One might debate whether this conclusion implies merely a qualification of the quantity theory or a fundamental rejection, but it clearly does not endorse a simple view of a proportional relation between money supply and the price level.

Curiously, this simple view is found in his analysis. The first statement on the quantity theory of money in that work is in chapter XII, of Mines and Barter (Cantillon 1759:25-33). This chapter commences the analysis of money by considering metals, like copper and silver, as products of mining activity similar to other commodities like lead, coal, and tin (ibid. 25-6): their 'value' is determined by their cost of production, i.e. the 'Value of Land and Labour made use of, while their 'price' varies with market demand, or more precisely 'according to the Taste, Luxury and will of the proprietors of land' (ibid. 26). Subsequently it is supposed that in a small state or community, with mines, but 'without foreign trade or interactions with its Neighbours', copper is introduced as money. Suppose that part of the metal is ordered to pass for money; it is clear that this new use for it, would cause a greater demand, and a greater quantity would be taken from the mines, than formerly, in order to supply this new demand (ibid. 27).

While this perhaps suggests a conception of the money supply as an 'endogenous' quantity, i.e. produced in response to the demand for it, in subsequent passages of chapter XXI money tends to be considered as a given quantity. Once metal (primarily silver and gold) came to be used as money, then 'by its quantity at market, it finds its proportion, by passing there at a fixed value in exchange for the land's produce. After explaining further 'how money operates in bringing about this proportion', in a passage that exhibits clear parallels with the famous example in the Essai (II, ii. Paragraph 2-4) of the determination of the market price of peas, the analysis considers the effects of a sudden increase in the money supply. In particular there is this striking statement of the quantity theory of money.

Bhatia (1981) informs us that Richard Cantillon 'remained in obscurity for well over a century even though Adam Smith and others knew about his work'. Cantillon's contributions were brought to the notice of the public in 1881 by Stanley Jevons. We are told that Jevons, when he discovered Cantillon's book, described it as 'the Cradle of Political Economy'.

Now we can see how superficial our economics knowledge would be if you were to leave out the history of Cantillon's ideas completely. These earlier philosophers were important in shaping both the content and the methods of economics. But as we stated in the opening paragraphs, none of them was given the credit for founding the subject. That credit went to Adam Smith. We shall next examine the concept of development, and how the contributions of this great philosopher have impacted the Nigerian economy so that we will have a better understanding of his ideologies.

\section{The Concept Of Economic Development}

Jhingan (2007) points out that economic development refers to the problems of under developed countries and economic growth of those of developed countries. Economic development goes beyond this to imply changes in the composition of output and in the allocation of inputs sectors. Kalu (2001) maintains that economic development is the ability of the people (the nation) to draw on domestic resources (human and material) to solve their problems. Further, he puts forward that economic development therefore embraces many more aspects of the economy than growth in output of goods and services. In short, it means growth has changes 
on the economy which affect the welfare of the people. Todaro and Smith (2006) observe that development economics has an even greater scope. In addition to being concerned with the efficient allocation of existing scarce (or idle) productive resources and with their sustained growth overtime, it must also deal with the economic, social, political and institutional mechanisms, both public and private necessary to bring about rapid (at least by historical standards) and large-scale improvements in levels of living standard for the peoples of different economies.

Kalu (2001) asserts that economists have suggested various parameters to measure development. Some of these are Gross National Product, Real Gross National Product per capita, physical volume of production. In addition Jhingan (2007) points out that there is also a tendency to measure economic development from the point of view of economic welfare. Therefore, economic development is regarded as a process whereby there is an increase in the consumption of goods and services of individuals. Furthermore, he argues that other indices include Physical Quality of Life Index (PILI), human development index: which include health, food and nutrition, education with emphasis in literacy and skills, employment conditions of work, consumption of basic necessities, transportation, housing including household facilities, clothing, recreation and entertainment, social security and others. Summers (2011), sees economic development as a wide, wonderful field that plays a critical role in our society and affects people's lives in a profound way. According to him, economic development covers many diverse disciplines, including economics, business, political science, public administration, marketing and communications, sociology, community planning, education, and many more. It engages a diverse variety of actors; including Federal, State, Local governments and development agencies, chambers of commerce, non-profit organizations, community development agencies, private enterprises, consultants and state development agencies,. Also, it occurs on different geographical levels (neighbourhoods, cities, metropolitan areas, states, multi- state regions, national, and international).

Wilson (2002) maintains that economic development can be determined by the following factors; economic factors (natural resources, human resources, capital formation or accumulation, technological progress, entrepreneurship, division of labour, scale of production and specialization, structural changes and foreign assistance. Others are non-economic factors, social factors, political, administrative factors and cultural factors. "Economic development" has been defined as "the process by which a community creates, retains, and reinvests wealth and improves the quality of life" (David Dodson, MDC, Inc). From this definition, one could see that David Dodson's definition of economic development laid emphasis on the concept of "quality of life". Certainly, the inevitable objective or goal of economic development is to improve the quality of life for the citizenry or nationals of a country. "It is not an end in itself, but a means to an end". Economic development, according to Porter, M. E. is the "long-term process of building a number of interdependent microeconomic capabilities and incentives to support more advanced forms of competition." These capabilities and incentives, which were originally identified in Porter's The Competitive Advantage of Nations, 1990, include the nature and extent of the inputs required by firms to produce goods or services; the rules, incentives and norms governing the type and intensity of local rivalry; the quality of demand for local services; and the extent and quality of local suppliers and related industries.

The World Bank often uses the following indicators in assessing the level and extent of development in several countries; these indicators include: GINI per capita, total population, Gross Domestic Product (GDP), Gross Domestic Product rate of growth, life expectancy at birth etc.

Table 1: World Development Indicators of Nigeria

\begin{tabular}{|c|c|c|c|c|c|c|c|c|c|}
\hline $\begin{array}{l}\text { Develo } \\
\text { pment } \\
\text { Indicat } \\
\text { ors }\end{array}$ & 2003 & 2004 & 2005 & 2006 & 2007 & 2008 & 2009 & 2010 & 2011 \\
\hline $\begin{array}{l}\text { GINI } \\
\text { per } \\
\text { capita, } \\
\text { PPP } \\
\text { (current } \\
\text { Internat } \\
\text { ional \$) }\end{array}$ & 1,320 & 1,460 & 1,540 & 1,800 & 1,860 & 1,960 & 2,040 & 2,160 & 2,290 \\
\hline $\begin{array}{l}\text { Populat } \\
\text { ion } \\
\text { total }\end{array}$ & $\begin{array}{l}133,067, \\
097\end{array}$ & $\begin{array}{l}136,399, \\
438\end{array}$ & $\begin{array}{l}139,823, \\
340\end{array}$ & $\begin{array}{l}143,338, \\
939\end{array}$ & $\begin{array}{l}146,951, \\
477\end{array}$ & $\begin{array}{l}150.665, \\
730\end{array}$ & $\begin{array}{l}154,488, \\
072\end{array}$ & $\begin{array}{l}158,423, \\
182\end{array}$ & $\begin{array}{l}162,470, \\
737\end{array}$ \\
\hline $\begin{array}{l}\text { GDP } \\
\text { (current } \\
\text { \$US) }\end{array}$ & $\begin{array}{l}67,655,8 \\
40,076\end{array}$ & $\begin{array}{l}87,845,4 \\
03,963\end{array}$ & $\begin{array}{l}112,248, \\
324,232\end{array}$ & $\begin{array}{l}145,428, \\
171,553\end{array}$ & $\begin{array}{l}165,920, \\
723,498\end{array}$ & $\begin{array}{l}207,115, \\
995,735\end{array}$ & $\begin{array}{l}168,587, \\
267,754\end{array}$ & $\begin{array}{l}228,637, \\
855,747\end{array}$ & $\begin{array}{l}243,985, \\
812,280\end{array}$ \\
\hline $\begin{array}{l}\text { GDP } \\
\text { growth } \\
\text { (annual } \\
\% \text { ) }\end{array}$ & 10 & 11 & 5 & 6 & 6 & 6 & 7 & 8 & 7 \\
\hline
\end{tabular}




\begin{tabular}{|l|l|l|l|l|l|l|l|l|}
\hline $\begin{array}{l}\text { Life } \\
\text { expecta } \\
\text { ncy at } \\
\text { birth, } \\
\text { total } \\
\text { (years) }\end{array}$ & 48 & 48 & 49 & 50 & 50 & 50 & 51 & 51 \\
\hline
\end{tabular}

Source: World Bank Development Indicators 2011(www.worldbank.org)

\section{The Relevance Of Richard Cantillon's Ideologies To Development Of The Nigerian Economy}

Although economists before and after Adam Smith were talking about development; they were interested mainly in the problems, which related to the industrialized economies of Western Europe and Northern America. A number of factors accounts for the increasing interest in development issues in relation to the relevance of the economic thoughts of the great economists. In this paper, efforts were made to analyze the economic thoughts of Richard Cantillon and Nigerian economic development by identifying the items that are included in his economic philosophy. Those items include the nature of wealth, social and economic organizations of people, entrepreneurship, wages of labour, theory of value, population problems and the use of gold and silver, barter, prices, money supply, circulation of money, interest rate; foreign trade, foreign exchange, banking and credit.

Looking at these items in relation to the desires of economic development on a general and global scale, it is obvious to point out that the wealth of Nigerian economy is not sustainable and evenly distributed among the populace, the country's wealth is concentrated in the hands of the limited few thereby leading to widespread poverty noticed in the country. The socio-seconomic organization of the people is not cordial due to the large number of ethnic groups existing within the country; it is estimated that Nigeria have about two hundred and fifty ethnic groups; the philosophy of "all people in Nigeria are one" is virtually dead or does not even exist. For example, a Hausa man does not see himself with an Igbo or Yoruba man as one and this have affected the Nigerian economy greatly, some ethnic groups within the country are even clamouring for the division of the country, until we see ourselves as one, no meaningful development can be achieved. The price of labour has been sustainably and relatively low; this is due to the fact that the supply of labour in Nigeria always exceeds the demand for labour. This is manifested by the high level of unemployment which exists in the Nigerian economy. Due to this; the reward for labour (wages and salary) will be low. The theory of value in Nigeria is in favour of corruption, as public office holders aid and abate the institutionalization of corrupt practices. Value is only attached to money, wealth and as such people especially the youths in the country will do anything to make money; they loot public treasury, engage in fraudulent practices such cyber theft etc in order to make money. Population problems have been on the increase in the sense that the birth rate is rising especially in the rural areas where they are not educated on family control measures, and this always outweighs the death rate. If this scenario is not checked and controlled, it will lead widespread level of poverty and fall in the living standard of the people. The use of gold and silver which in the Nigerian context is crude oil has rather been a curse instead of blessing to the Nigerian nation. This is due to the fact that since the country starting exporting crude oil, there have been a neglect of other sectors of the economy and the revenue gotten from the export of crude oil have not been used to develop other sectors of the economy, instead it has been mismanaged and embezzled by our political leaders. In fact, surprisingly barter system has not been completely eradicated in the Nigerian economy, inflation (continuous general increase in the prices of goods and services) has been sustainable in Nigeria, and money is being institutionally circulated into the purse of political office holders instead of the real sector of the economy. The personal affairs of the political office holders have become a good and functional model for circulation flow of income rather than considering the real sector of the economy. Interest rates in most financial institutions operating in the country are high, hence discouraging potential local investors from investing in the economy; as a result of that Nigeria has ostensibly no place in the international trade and this has accounted for why the foreign exchange rate has not been in our favour, thus, Nigeria has no place in the foreign trade. The alleged corrupt practice in the banking sector in terms of provision of credit facilities to the real sector has become another issue of discourse.

In order to revert most of these negative trends that affects the economic development of the Nigerian economy, we can adopt some of Cantillon's philosophy and ideologies, and if implement sincerely would lead the Nigerian economy to the path of economic development and prosperity

\section{Conclusion And Recommendations}

This paper examines the work of Richard Cantillon and identified the prominent role it plays in the development of the Nigerian economy if it is implemented effectively by the Nigerian government. From the above it is obvious that the Nigerian economy is not developed because among others, the wonderful ideas and philosophy of great economists such as Richard Cantillon have not been applied sincerely through the 
formulation and implementation of economic policies in the country. Based on the foregoing, the following recommendations are advanced for prompt and adequate policy actions. The Monetary Authorities and Ministry of Finance should collaborate with one another in the implementation of effective monetary and fiscal policies in the Nigerian economy. Also, there should be a proper value reorientation in the attitudes and minds of the Nigerian citizenry with regard to what they should attach value to and seeing themselves as one rather than different people. The attention of the Debt Management Office (DMO) should be drawn to the adverse effects of borrowing from external sources such as the London club and Paris club. The financial authorities should ensure that the interest rate charged on loans, especially the domestic components should be monitored, if not, given its present magnitude may crowd out local private investors. The government should diversify the productive base of the economy especially the non oil sector so as to boost exports and create more employment for its increasing labour force.

\section{[1]. References}

[2]. Akpakpan, E. B. (1999): The Economy: Towards A Type of Economics. Belpot Publishers, Port Harcourt

[3]. Bhatia, H. L. (2006): History of Economic Thought. Vikas Publishing House PVT Ltd, New Delli.

[4]. Kalu, I. E. (2001): Issues in Problems and Policies of Development. Techno Consult Ltd, Lagos.

[5]. Laidler, D. (2008): The Role of the History of Economic Thought in Modern Macroeconomics. University of Western Ontorio.

[6]. Marcuzzo, M. C. (2008): Is History of Economic Thought a serious subject? Erasmus Journal for Philosophy and Economics, Vol 1. Issue 1 .

[7]. Ohale, L. and Onyema, J. I. (2003): Foundations of Macroeconomics. Amethyst \& Colleaque Publishers, Port Harcourt.

[8]. Okowa, W. J. (1996): How the tropics Underdeveloped the Negro: A Questioning theory of Development. Jeson Services. Port Harcourt.

[9]. Porter, M. E. (1990): The Competitive Advantage of Nations, Free Press, New York.

[10]. Summers, J. A. (2011): Economics Development: Broadly Defined. Ecdi.wordpress.com

[11]. Tamuno, S. O. (2006): A Synoptic view of Economic Theories. African Heritage Publications, Lagos.

[12]. Jhingan, M. L. (2007): The Economics of Development and Planning, $39^{\text {th }}$ Edition. Vrinda Publications (PD Ltd, Delli.

[13]. Todaro, M. P. and Smith, S. C. (2006): Economic Development, Pearson Educational Limited, England.

[14]. Van den Berg, R. (2009): Richard Cantillon's Early Monetary Views. Journal of Economic History, vol 8, No 9.

[15]. Wilson, G. (2002): Development Economics: A Concise Text. Pearl Publishers, Port Harcourt. 